DOI: https://doi.org/10.32839/2304-5809/2021-5-93-48

UDC 81'25

Turchyn Yuliia, Hrytsiv Nataliia

Lviv Polytechnic National University

\title{
LEXICAL AND GRAMMATICAL TRANSFORMATION IN THE TRANSLATION OF POLITICAL DISCOURSE
}

Summary. The study deals with the issue of lexical and grammatical transformations used by translators in the process of translating the texts of political news from NATO`s official website. In this article, the definition of the term "translator's transformations" based on the analysis of different scholars' points of view on this matter was suggested. Various classifications of translation transformations were mentioned. The paper highlights the reasons for using lexical and grammatical transformations in translation, and why these transformations are helpful for translators. The analysis of the use of the features and patterns of translation techniques to achieve the adequacy of translation was performed. In the article transformations in the translation of the texts of political news (from the NATO official website) were examined. The research is focused on the main characteristic features and peculiarities of using grammatical and lexical transformations in the process of translating political texts. The research object is transformations in translation of the texts of political news (from the NATO official website). The research subject is the features and principles of using grammatical and lexical transformations in the process of translating political texts. The results of the research indicate the most characteristic lexical and grammatical transformation in the translation of political news and the frequency of their use.

Keywords: translation, lexical transformation, grammatical transformation, adequate translation, generalization, compensation, permutation, replacement, addition, omission.

Турчин Ю.М., Гриців Н.М. Національний університет «Львівська політехніка»

\section{ЛЕКСИЧНІ ТА ГРАМАТИЧНІ ТРАНСФОРМАЦІЇ ПРИ ПЕРЕКЛАДІ ПОЛІТИЧНОГО ДИСКУРСУ}

\begin{abstract}
Анотація. Стаття присвячена проблемі лексичних та граматичних трансформацій, які використовують перекладачі в процесі перекладу текстів політичних новин з офіційного веб-сайту НАТО. У цій статті було запропоновано визначення терміну «перекладацькі перетворення» на основі аналізу поглядів різних вчених на це питання. Згадано різні класифікації перекладацьких перетворень. Також висвітлено причини використання лексичних та граматичних перетворень у перекладі та чому ці перетворення корисні для перекладачів. Було проведено аналіз використання особливостей та закономірностей перекладацьких методів для досягнення адекватності перекладу. Робота включає наступні етапи: визначити сутність поняття "перекладацька трансформація" та "граматична і лексична трансформація"; розглянути основні класифікації граматичних та лексичних трансформацій, підходи до їх поділу на морфологічному та синтаксичному рівнях; проаналізувати особливості використання цих трансформацій на практиці на прикладі перекладу текстів політичних новин; визначити роль трансформащії у перекладі політичних текстів та провести кількісний та якісний аналіз знайдених трансформацій; оцінити адекватність переклад цих текстів. Об’єктом дослідження є трансформації при перекладі текстів політичних новин (з офріційного веб-сайту НАТО). Предметом дослідження є особливості та принципи використання граматичних та лексичних трансрормацій у процесі перекладу політичних текстів. Результати дослідження вказують на найбільш характерну лексико-граматичну трансформацію при перекладі політичних новин та частоту їх використання.
\end{abstract}

Ключові слова: переклад, лексичне перетворення, граматичне перетворення, адекватний переклад, узагальнення, компенсація, перестановка, заміна, додавання, вилучення.

Droblem statement. Nowadays great attention has been paid to the study of the translation process by translation theorists and practitioners. The problem of translation transformations as a problem of translation theory and practice is of great interest to both domestic and foreign scholars and is becoming increasingly important.

Transformations are an integral part of the translation. The issue of using translation transformations in texts of different functional language styles is also relevant. When translating texts of different functional styles, preference is given to different types of transformations, and therefore it is appropriate to conduct research aimed at identifying the most commonly used transformations and characteristics of texts of a particular functional style of language.
The latest research and published works analysis. The problem of translation transformations has been considered by many linguists who have proposed their definition of this concept. The study of various transformations was not a fundamentally new idea. Both domestic and foreign scholars devoted their works to the study of lexical and grammatical transformations, namely: L. Barkhudarov, S. Maksimov, V. Karaban, V. Komissarov, V. Koptilov, L. Latyshev, L. Levitska, A. Mamrak, O. Semenov, A. Fitterman, A. Schweizer and others.

In particular, J. Retsker made the first attempt to comprehend interlingual transformations theoretically. Retsker's merit was that he drew attention to the regularity of transformations in translation and divided translation transformations into two groups: lexical and grammatical [5]. 
L. Barkhudarov singled out four types of elementary translation transformations: permutation, replacement, addition and omission [1].

Identification of previously unsettled parts of the general problem. The course paper investigates translation transformations as a way to achieve equivalence in the translation of political texts. The topicality of the theme is determined, on the one hand, by absence of a clear definition of the phenomenon under study, and on the other hand by significant differences in the structure of English and Ukrainian languages and therefore the topical issue is the identification and consideration of typical nuances of political texts translation in different language levels and their structural and semantic interaction.

This article aims to identify the features and patterns of grammatical and lexical transformations in the translation of political texts from English into Ukrainian, to study the use of translation techniques to achieve the adequacy of translation.

The objectives of the study encompass the following aspects:

1) to define the essence of the concept of "translation transformation" and "grammatical and lexical transformation";

2) to consider the main classifications of grammatical and lexical transformations, approaches to their division at the morphological and syntactic level;

3) to analyze the features of the use of these transformations in practice on the example of the translation of the texts of political news;

4) to identify the role of the transformation in the translation of political texts and conduct a quantitative and qualitative analysis of the found transformations;

5) to estimate the adequacy of translation of these texts.

The main part. The basic and important task of translator while translating political news was to transmit the main idea by means of another language preserving coherence and cohesion of the original text and the expressive and stylistic peculiarities in the translated text. That process was practically impossible without some losses. In the process of translation a source language text as a whole or its segments may undergo varied modifications (lexical and grammatical transformation).

A study of theoretical sources on the stated subject proves that translation requires the use of lexical and grammatical transformations, as translator is constantly dealing with certain difficulties associated with differences in the lexical and grammatical systems of the original language and the target language.

We translated journalistic texts from the field of political news, in which lexical and grammatical translation transformations were found and processed.

Lexical transformation in the translation of the texts of political news.

Lexical transformations - deviations from direct vocabulary correspondences. Lexical transformations are caused mainly by the fact that the volume of meanings of the lexical units of the original language and the languages of translation does not coincide [2]

Lexical transformation used to reach the adequacy in Ukrainian translation of English texts of political news on NATO website are:
1) Transliteration - formal reproduction of the original English lexical unit with the help of the alphabet of the Ukrainian language, letters imitation of the form of the source word. For example:

- Secretary General Jens Stoltenberg announced the appointment of a group of experts on Tuesday (31 March 2020) to support his work in a reflection process to further strengthen $\mathbf{N A}$ TO's political dimension. The group of five men and five women will be co-chaired by Thomas de Maizière and Wess Mitchell, and will report to the Secretary General. $\Rightarrow$ Генеральний секретар Снс Столтенберг, у вівторок, 31 березня 2020 року, оголосив про призначення групи експертів на допологу йому в облірковуванні питань подальшого зміцнення політичного виміру НАТО. В групі з п'яти чоловіків $і$ n'яти жінок, яка звітуватиле перед Генеральнил секретарел, головуватилуть Толас де Мазієр i Вес Мітчелл [11].

In this case, transliteration was used to translate proper names (names of people and organization).

2) Tracing - reproduction not of sound, but of combinatorial syllable of a word or phrase, when the constituent parts of a word (morpheme) or phrase (lexeme) are translated by the corresponding elements of the translation language:

- It was co-organised by NATO's Defence Education Enhancement Programme (DEEP) and the Partnership for Peace Consortium. $\Rightarrow$ Зaxid було спільно організовано програлою НАТО з удосконалення військової освіти (DEEP) $i$ консориіулол Партнерства заради миру [11].

- The previous three iterations of the NCO professionalization workshop were hosted by Georgia from 2016 to 2016. $\Rightarrow$ Попередні mpu селінари, присвячені профбесіоналізашї ССС, проводились в Грузії із 2016 до 2019 року [11].

3) Concretization is a method of translation which results in a replacement of a word or phrase of the English language with a broader subject-logical meaning by a word or phrase with a narrower meaning in translation [1]:

- "We will continue to consult, monitor the situation and take all necessary measures," he said. $\Rightarrow$ "Ми продовжимо консультаиї, моніторинг ситуаиї $i$ здійснюватилело усі необхідні заходи", -зазначив він [11].

In Ukrainian version, the translator uses a word of narrower meaning "зауважити" instead of the general word "сказати".

- It was co-organised by NATO's Defence Education Enhancement Programme (DEEP) and the Partnership for Peace Consortium. $\Rightarrow$ 3axid було спільно організовано програлою НАТО 3 удосконалення військової освіти (DEEP) $i$ консориіулол Партнерства заради миру [11].

The translator uses concretization to emphasize or narrow the meaning, to achieve greater accuracy and clarity.

4) Modulation, or semantic development - is the replacement of a word or phrase of the original language with a word or phrase in the language of translation, the meaning of which can be deduced logically from the original meaning. Semantic development, as well as other types of lexical transformations, does not concern a single word, but at least a phrase, a certain semantic group: 
-It will offer recommendations to reinforce Alliance unity... $\Rightarrow$ Мають бути вироблені рекомендації щодо зміцнення єдності Альянсу...[11].

- This project is the successor to the NATO SATCOM... $\Rightarrow$ Цей проект прийшов на зміну проекту НАTO SATCOM...[11].

5) Generalization involves the replacement of a unit of the original language, which has a narrower meaning, with the unit with a broader meaning in the language of translation, i.e. transformation, that is the reverse of the concretization [1]:

- Documents related to the Non-Proliferation Treaty are publicly disclosed. $\Rightarrow$

НАТО без секретів: оприлюднені документи, що стосуються Договору про нерозповсюдження [11].

- ...the satellite communications capability to deliver services to $N A T O . \Rightarrow$...засобів супутникового зв'язку, які обслуговують НАТО [11].

Thus, the method of generalization, is used due to certain differences in the syntagmatic compatibility of equivalents in English and Ukrainian, different stylistic norms of languages, as well as lexical and semantic differences, often involving grammatical change by omission.

In general, 17 transliterations, 8 tracing, 7 concretizations, 7 generalizations and 5 modulations were found in the research material.

Grammatical transformation.

A study of theoretical sources on the stated topic proves that translation requires the use of grammatical transformations, as translators are constantly dealing with certain difficulties associated with differences in the grammatical systems of the original language and the language of translation.

It has been established that grammatical translation transformation means a change in the grammatical characteristics of a word, phrase, or sentence in a translation used to avoid grammatical literalism. Because of grammatical translation literal translation adapts to the norms of the language of translation and becomes adequate.

Having analsed the text of the translation of political news we found the following grammatical transformations (the number of found examples are given in parentheses):

1) permutation (transposition or inversion)(37examples) - is a grammatical transformation that changes the order of words in a phrase or sentence [5].

Words, phrases, parts of a complex sentence, as well as independent sentences in the text of researched political news were transposed:

- Secretary General Jens Stoltenberg announced the appointment of a group of experts on Tuesday (31 March 2020) to support his work in a reflection process to further strengthen NATO's political dimension. $\Rightarrow$ Генеральний секретар Єнс Столтенберг, y вівторок, 31 березня 2020 року, оголосив про призначення групи експертів на допомогу йому в обмірковуванні питань подальшого зміцнення політичного виміру НАТО [11].

The reasons for the application of the permutation are the differences between the systems of English and Ukrainian languages, first of all, it is the lack of strict word order in the Ukrainian language, as it is in English.

- At their meeting in London last year, NATO leaders agreed to a forward-looking reflection pro- cess under the auspices of the Secretary General. $\Rightarrow$ На своему засіданні у Лондоні минулого року лідери НАТО (Transposition) домовились про початок прочесу обмірковування майбутнього під егідою Генерального секретаря НАТО [11].

Grammatical inversion is used here because the inverted word order is the only way possible for the given grammatical construction.

- This project is the successor to the NATO SATCOM Post-2000 project, which provided SATCOM services to NATO from 2005 to 2019. $\Rightarrow$ Цей проект прийшов на зміну проекту НАТО SATCOM Post-2000, який забезпечував НATO послугали супутникового зв'язку із 2005 до 2019 року [11].

If a translator decided to make a word-to-word translation, this sentence would look quite unnatural for Ukrainian speakers, so we have an inverted variant.

2) Replacement is resulted in changing grammatical indications of word forms, parts, and members of the sentence [5]. All parts of speech, all members of a sentence, and all syntactic constructions take part in these transformations, it explains their number and variety. For example:

- Replacement of Parts of Speech (47).

- It will offer recommendations to reinforce Alliance unity, increase political consultation and coordination between Allies, and strengthen NATO's political role. $\Rightarrow$ Мають бути вироблені реколендацї, щодо злічнення єдності Альянсу, покращання політичних консультацій $i$ координацї між членалиАльянсу і посилення політичної ролі НАTO [11]. (Infinitives in the translation are transformed into Nouns).

- ... a request for international assistance from the Department of firefighters, public rescue and civil defense of the Italian Ministry of the Interior... $\Rightarrow$...запит про міжнародну допомогу від департаменту пожежної безпеки, рятувальних робіт $i$ иивільного захисту італійського Міністерства внутрішніх справ... [11].

- NATO and Serbia boost cooperation on defence education. $\Rightarrow$ HАTO i Сербія поглиблюють співробітниитво в галузі військової освіти [11]. (Nouns in the translation are transformed into Pronouns).

- Mr. Stoltenberg stressed that NATO remains committed to its mission... $\Rightarrow$ Пан Столтенберг наголосив, що НАТО продовжуе виконувати свою місію... [11]. (Participle in translation is transformed into Infinitive).

- While results naturally vary across different countries... $\Rightarrow$ Хоча результати в різних краӥнах piзні...[11]. (Verb is transformed into Adjective).

- ...he said that "NATO also aims to serve as a forum for political-military consultations... $\Rightarrow \ldots$. $_{\mathrm{w}}$ "НАТО також має на меті слугувати бборумом для політико військових консультацій... [11]. (Verb is transformed into Word combination).

The results of the study suggest that one of the most commonly used structural changes is the replacement of parts of speech. The translator uses them the cases when there is no part of the language or construction in the Ukrainian language with the appropriate meaning when the norms of compatibility require it. 
- Replacement of Word forms (5):

- Nations began delivering the capability on 1 Jапиагу 2020. $\Rightarrow$ Держави розпочали надавати иі засоби 1 січня 2020 року [11]. (Instead of the singular form, the plural form is used in translation).

- Replacement of Tense Paradigms (10)

The reason for the use of grammatical tense replacement is the presence of a grammatical category of the aspect in the Ukrainian language. English has lost this category, acquiring instead many grammatical tense forms of verbs. For instance:

- The Serbian Armed Forces have been implementing a number of activities... $\Rightarrow$ Сербськi збройні сили із 2013 року впроваджують ряд заходів... [11].

In this case, the English tense form of the verb Present Perfect Continuous was transformed in Ukrainian using the present tense form "впроваджують", because in Ukrainian language there is no similar grammatical form that would accurately convey the original version.

- Replacement of Voice Paradigms (7):

- The previous three iterations of the NCO professionalization workshop were hosted by Georgiа... $\Rightarrow$ Попередні три семінари, присвячені профбесіоналізацї ССС, проводились в Грузії.. [11]. (Passive voice of the verb is transformed in an active one)

- It will offer recommendations to reinforce Alliance unity... $\Rightarrow$ Мають бути вироблені рекомендації, щодо зліцнення єдності Альянсу... [11]. (Active voice of the verb is transformed into a passive one) (12):

- Replacement of Members of a Sentence

In addition to changing the forms of words and parts of speech at the syntactic level, there is a change in the members of the sentence. A more significant reorganization of the syntactic structure is associated with a change of subject:

- The workshop aimed at discussing how the presented PME programmes are aligned with the NATO NCO PME Reference Curriculum, as well as how DEEP Programme can be employed for the future initiatives in this domain. $\Rightarrow$ Метою селінару було обговорення відповідності програм ПВО типовій програлі ПВО ССС НАТО, а також можливості застосування програли DEEP для майбутніх ініціатив у иій сфбері.(Subjects are transformed into objects).

- On Wednesday (12 February 2020) NATO held a ceremony to mark the conclusion of a Memorandum of Understanding... $\Rightarrow$ У середy, 12 лютого 2020 року, в НАТО відбулась церелонія, присвячена укладанню Меморандуму про розуміння... [11]. (The object is transformed into the subject).

- The composition of the group advising the Secretary General on the reflection process takes into account gender balance... $\Rightarrow$ При фбормуванні групи радників Генерального секретаря з иих питань було взято до уваги гендерний баланс... [11]. (Subject is transformed into circumstance).

The translator uses a change of subject, wanting to make the translation more idiomatic, i.e. to deal with those expressions that are more commonly used in the language of translation.
- Replacement of Type of a Sentence (9):

We found also grammatical transformations at the syntactic level, involving the replacement of a complex sentence with a simple one and vice versa:

- The group of five men and five women will be co-chaired by Thomas de Maizière and Wess Mitchell, and will report to the Secretary General. $\Rightarrow B$ групі з п'яти чоловіків $i$ n'яти жінок, яка звітуватиле перед Генеральнил секретарел, головуватимуть Томас де Мазіер $i$ Вес Мітчелл [11]. (Simple sentence is transformed into complex one).

1) Translation by the mean of complex transformation (10)

The complex grammatical transformation includes two or more simple grammatical transformations, for example:

- Adding that space is essential for the Alliance's deterrence and defence, he said that "NATO also aims to serve as a forum for political-military consultations...". $\Rightarrow$ Зазначивши, що кослос мат велике значення для стримування $i$ оборони Альянсу, він сказав, що "НАТО також мак на леті слугувати фборумол для політико військових консультацій..." [11].

In the translation Replacement of Part of Speech and Addition is carried out simultaneously.

- ...has been working for many years to strengthen the resilience of Allies, including the health sector. $\Rightarrow$... працюе над зміцненнял стійкості членів Альянсу, зокрема в сфбері охорони здоров'я [11]. (Transposition and Addition).

The percentages of grammatical transformations found in our political texts is as follows: permutation $16,9 \%$, replacement of parts of speech $21,5 \%$, replacement of members of a sentence $5,5 \%$, complex transformation $4,6 \%$, replacement of tense taradigms $4,6 \%$, replacement of type of of a sentences $4,1 \%$, replacement of voice paradigms $3,2 \%$, replacement of word forms $2,3 \%$.

Lexico-grammatical features of translation of the studied material.

Some transformations in our texts involved both lexical and grammatical alterations.

Transformations of addition and omission of words turned out to be quite frequent when translating political texts (29 and 10 examples of use, respectively).

2) Addition is a grammatical transformation, as a result of which the number of words, word forms, or members of a sentence increases in translation [5].

Addition was used in the translation of nouns, verbs, adjectives, adverbs, words of other parts of speech, and phrases in our texts. The addition of words in the vast majority of cases is dictated by the use of descriptive translation:

- ...increase political consultation and coordination between Allies... $\Rightarrow$...nокращання політичних консультацій $i$ координації між членали Альянсу...[11].

- Ministry of Interior of Italy requests international assistance in their response to COVID-19 $\Rightarrow$ Міністерство внутрішніх справ Iталіі просить про міжнародну допомогу в подоланні COVID-19 [11].

The translator specifies the English nouns Allies and Interior, adding the Ukrainian nouns 
"члени" and "справи", respectively, without which the meaning of these sentences would not be sufficiently clear.

Differences in the grammatical tenses of the English and Ukrainian languages lead to the frequent use of the addition technique in translation, by which these differences are minimized and the meaning is transmitted as close as possible to the original:

- More broadly, the Annual Report for 2019... $\Rightarrow$ У ииршолу сенсі, в Щорічній доповіді за 2019...[11].

- Adding that space is essential for the Alliance's deterrence and defence... $\Rightarrow$ Зазначивши, шо кослос лає велике значення для стрилування $i$ оборони Альянсу...[11].

- NATO has been working for many years to strengthen the resilience of Allies, including the health sector. $\Rightarrow$ HАTO багато років працюе над зліиненнял стіикості членів Альянсу, зокрела в собері охорони здоров'я [11].

4) Omission is such a grammatical transformation, which is resulted in removing a certain speech element [5].

We are dealing with the omission of redundant language units in the translation. In most cases, these are elements that relate to the structure of language. For example:

- The following people have been appointed to the group... $\Rightarrow$ До групи призначені ... [11].

- Participants from NATO Allies and partner countries presented their respective programmes for the formation of Non Commissioned Officers $\Rightarrow$ Учасники з країн-членів $i$ партнерів Альянсу представляли свої програли підготовки сержантського і старшинського складу [11].

The reason for removing some components of the English sentence is the lack of grammatical phenomena or elements in Ukrainian language:

- ...the steps NATO is taking to limit the spread of the virus... $\Rightarrow \ldots \kappa р о к и$, які НАTO здійснюе задля облеження поширення вірусу... [11].

In this case, the auxiliary word 'is', which is used to form the English time form Present Continuous and is not typical for the Ukrainian language, was removed.

In the following case, an English word-connection 'is' was deleted:

- ...overall support for NATO is strong... $\Rightarrow \ldots$ загальна підтримка НАТО потужна... [11].

Conclusions. It is well known that the translation process is not a simple replacement of units of one language with units of another language. On the contrary, it is a difficult process that involves a number of difficulties that a translator must overcome. One of the ways that facilitates the translator is transformation.

Despite a large amount of research in this field, the problem of translation transformations in general and lexical and grammatical transformations, in particular, remains relevant. Transformations at any level are an integral part of translation activities, and any professionally performed translation includes certain types of transformations, the features, and expediency of which require constant research in to further improve the level of translation competence.
The analysis of lexical transformations found in texts of political news made us draw the following conclusions:

1. To translate the vocabulary of political texts from English into Ukrainian, such translation transformations as transliteration, tracing, concretization, generalization, and modulation are used.

2 . The use of these devices is mainly due to the differences in the lexico-grammatical systems of the two languages, differences in their stylistic norms, rules of syntagmatic compatibility of tokens.

3. The most frequent translation transformation is the transliteration and concretization $(7,8 \%$ and $3,2 \%$ respectively). Prevalence of the usage of the concretization in the translation from English into Ukrainian language is due to a large number of English words with general semantics, which have no direct equivalent in the Ukrainian language. The point is that one word in English language that expresses the broader meaning, can meet two or more words in Ukrainian language, each of which expresses a narrower concept compared to the English language that applies to a limited class of denotations.

As for the grammatical transformation, examples of permutation and replacement were found in our political texts. The results of the study show that one of the most commonly used structural transformations is the replacement of parts of speech $(37.3 \%)$, in particular, verbs by nouns. The translator uses it when there is no part of the language or construction in the Ukrainian language with the appropriate meaning when the norms of compatibility require it. Quite common are also the replacement of members of a sentence $(5,5 \%)$ and syntactic structures of the original text $(4,1 \%)-$ words by phrases, complex sentences by simple and vice versa. The reason for the use of grammatical tense replacement $(4,6 \%)$ is the absence of the grammatical category of the aspect in the target language.

When translating the analyzed work, permutations $(16,9 \%)$ are most often used in the case of the transfer of English adverbs, possessive cases and caused by differences in the placement of main and secondary members of the sentence in English and Ukrainian.

It is also worth noting that grammatical changes are often accompanied by other translation transformations, including lexical ones. On the example of the translation of texts of political news from English into Ukrainian we have identified the following lexico-grammatical transformations: addition and omission. Additions in translation occur mainly due to the absence of a grammatical phenomenon in the language of translation. Also, this grammatical transformation is widely used in the transfer of English polysemous verbs, whose translation into Ukrainian requires introducing additional components in order to concretize them. Omission is usually used in the case of translation of words, word forms, members or parts of a sentence that are redundant, i.e. are pleonastic in nature.

Therefore, we carried out the analysis of translation transformations in the texts of political news and found main features and principles of using grammatical and lexical transformations in the process of translating of these texts. 


\section{References:}

1. Barkhudarov L.S. (2010) Yazyk i perevod: Voprosy obshchey i chastnoy teorii perevoda [Language and translation: Questions of general and specific theory of translation]. Moscow: Leningrad Shipbuilding Institute. (in Russian)

2. Komissarov V.N. (2001) Sovremennoye perevodovedeniye [Modern translation studies]. Moscow: Electronic and Traditional Dictionaries. (in Russian)

3. Latyshev L.K. (1981) Kurs perevoda. Ekvivalentnost $i$ sposoby yeyë dostizheniya [Equivalence and ways to achieve it]. Moscow: International relations. (in Russian)

4. Maksimov S.Ye. (2006) Praktychnyi kurs perekladu (anhliiska ta ukrainska movy) [Practical translation course (English and Ukrainian)]. Kyiv: Lenvit. (in Ukrainian)

5. Mamrak A.V. (2009) Vstup do teorii perekladu [Introduction to translation theory]. Kyiv: Center for Educational Literature. (in Ukrainian)

6. Retsker Ya.Y. (1974) Teoryia perevoda y perevodcheskaia praktyka [Translation theory and translation practice]. Moscow: International relations. (in Russian)

7. Semenov A.L. (2005) Osnovnye polozhenyia obshchei teoryy perevoda [The main provisions of the general theory of translation]. Moscow: Peoples' Friendship University of Russia Publishing House. (in Russian)

8. Shveitser A.D. (1988) Teoryia perevoda. Status, problemy, aspekty [Translation theory. Status, problems, aspects]. Moscow: Science. (in Russian)

9. Lapinska O.M. (2014) Grammatical transformations in scientific-technical translation. Bulletin of Dnipropetrovsk University: Linguistics, vol. 22, no. 20(1), pp. 97-101.

10. Rusu A. (2015) Difficulties in translation of grammar transformations. Free International University of Moldova, № 1-2(34), pp. 221-225.

11. URL: https://www.nato.int/cps/en/natohq/news.htm

\section{Список літератури:}

1. Бархударов Л.С. Язык и перевод: Вопросы общей и частной теории перевода. Москва : Изд-во ЛКИ, 2010.238 с.

2. Комиссаров В.Н. Современное переводоведение. Москва : ЭТС, 2001. 424 с.

3. Латышев Л.К. Курс перевода. Эквивалентность и способы её достижения. Москва : Международные отношения, 1981. $198 \mathrm{c}$.

4. Максімов С.Є. Практичний курс перекладу (англійська та українська мови) : Навчальний посібник. Київ : Ленвіт, 2006. 157 с.

5. Мамрак А.В. Вступ до теорії перекладу. Київ : Центр учбової літератури, 2009. 304 с.

6. Рецкер Я.И. Теория перевода и переводческая практика. Москва : Международные отношения, 1974. 216 с.

7. Семёнов А.Л. Основные положения общей теории перевода. Москва : Изд-во Российского ун-та дружбы народов, 2005. $99 \mathrm{c}$.

8. Швейцер А.Д. Теория перевода. Статус, проблемы, аспекты. Москва : Наука, 1988. 364 с.

9. Lapinska O.M. Grammatical transformations in scientific-technical translation. Вісник Дніпропетровського університету. Сер. : Мовознавство. 2014. Т. 22. Вип. 20(1). С. 97-101.

10. Rusu A., Difficulties in translation of grammar transformations. Free International University of Moldova. 2015. № 1-2(34). Pp. 221-225.

11. URL: https://www.nato.int/cps/en/natohq/news.htm 